The inaugural address will be delivered by Sir Walter Langdon-Brown, emeritus professor of physic in the University of Cambridge. The following speakers have undertaken to give lectures and take part in discussions: Prof. J. C. Drummond, scientific advisor, Ministry of Food; Dr. Leslie J. Harris, director of the Nutritional Laboratory, University of Cambridge ; Dr. Grace Calver, physician, Children's Department, Tavistock Clinic ; Mrs. C. Neville-Rolfe, past vice-president, Eugenics Society; Sir Drummond Shiels, medical secretary, British Social Hygiene Council ; Mrs. E. J. Hatfield, North London Collegiate School; Mr. R. Weatherall, Eton College ; and Miss V. D. Swaisland, British Social Hygiene Council. Further information can be obtained from the Education Officer, British Social Hygiene Council, Inc., Tavistock House South, Tavistock Square, London, W.C.1.

\section{International Relief Union}

THE origin, aims, means and future of the International Relief Union are discussed by M. Camille Gorgé in a pamphlet recently issued by the Union (Geneva: International Relief Union). M. Gorgé points out that, for good or for ill, the States of the world have become so closely welded together that they form a great family from which no one member can dissociate himself without serious inconvenience or actual hardship. Although international co-operation has at present lost most of its vitality and force, sooner or later the nations must revert to the method of collective agreements, and use the instruments or machinery already established for that purpose. The International Relief Union, which was established by the Convention of July 12, 1927, was largely the outcome of a scheme elaborated by $\mathbf{M}$. Giovanni Ciraolo to provide not only for immediate and organized relief for peoples overtaken by disasters, such as earthquakes or other catastrophes arising from natural causes, epidemics, famine, etc., but also for the scientific study of the causes of natural calamities, with the view of counteracting or limiting their effects. According to the Convention, the International Relief Union has a fourfold task : it must furnish first aid to the populations that are victims of public disasters, and co-ordinate, as occasion offers, the efforts made by other relief organizations; it must also encourage the study of preventive measures against disasters and seek to induce all peoples to render mutual international assistance.

The Convention did not come into force until December 27, 1932, and its financial resources were too limited for it to do its work freely and effectively. Special stress is laid upon the mobilization of the forces of good will against adversity beyond national frontiers, and upon encouraging scientific men to study how ta combat or even counteract future disasters. Scientific workers are urged to co-ordinate research in all its branches so that the various communities may unite their concrete efforts, based on accurate data, to minimize the damage to the human family caused by great scourges. Aviation and broadcasting have already done something to reduce the gravity of certain disasters, and fresh opportunities of foresight and defence continually arise. To assist scientific workers to explain their ideas and compare results in this field, the Union in June 1938 issued the Revue pour l'étude des calamities, replacing the Matériaux pour l'étude des calamities, previously published by M. Montandon in collaboration with the Société de Géographie de Genève. One of the first tasks of the Union in this field is to make a detailed study of the geography of natural disasters. A resolution of the first International Conference for Protection against Disasters, Paris, September 1937, recommended that the Union should consider the appointment of a Permanent International Committee for Protection against Disasters, collaborating with the Board of Scientific Documentation of the Union, and M. Gorgé briefly indicates directions in which such concerted scientific effort is required.

\section{Wood Pole Transmission Lines}

IN order to examine the incidence of risks from shocks and fire due to the use of wood-pole transmission lines, tests were undertaken of primary insulation at 19,11 and $6 \cdot 35 \mathrm{kv}$. The work is described by. G. T. Garwood in the Electrical Review of April 12. The structure on which the tests were carried out comprised a plain-sawn English oak cross-arm, 5 in. by 3 in., bolted to a red fir-pole, $32 \mathrm{ft}$. by $11 \frac{1}{4} \mathrm{in}$. in diameter at $5 \mathrm{ft}$. from the butt. The pole was sound in every way and had been creosoted. The instruments used for the tests were two electrostatic voltmeters. The resistance between the cross-arm bolt and earth was measured on frequent occasions in the period during which the test was being taken and also under varying conditions of dryness. The megger readings ranged from 200,000 ohms with the pole dry to 50,000 ohms with it wet. With the $11 \mathrm{kv}$. connexions a current of 140 micro-amperes could be obtained from below a plain earthing collar. As 15 micro-amperes may give a fatal shock to a normal man, if his heart lie in the circuit, the experiments showed that a plain earthing collar round the pole is insufficient protection. In the destruction tests, about ten minutes after the wetting of the pole smoke appeared from the cross-arm near the insulator pin. Longitudinal 'shakes' opened up in the cross-arm and showed signs of carbonizing. After about twenty minutes, smoke appeared from these shakes, the source of the smoke moving steadily towards the pole. After thirty minutes, smoke appeared from the pole top and 'tracking' with small intermittent flames at the earthing collar. Heavy smoke and flames appeared at the pole-top after seventy-five minutes and after eighty-five minutes the test was stopped, it being clear that the complete destruction of the structure was inevitable.

\section{Flavour of Bacon}

The Department of Scientific and Industrial Research has issued a report describing work carried out for the Food Investigation Board on the importance of various factors responsible for the pro- 
duction of flavour in bacon and ham (Food Investigation Special Report No. 49. "The Function of Nitrate, Nitrite, and Bacteria in the Curing of Bacon and Ham". H.M. Stationery Office. 9d. net). Curing of pork for bacon and ham was originally a process of dry salting. Now, the pickle used is liquid, and the process is supplemented by injecting the pickle into the tissues of the carcass. The traditional pickling materials - salt and saltpetre-are still used in Great Britain, but it has long been known that the 'cured colour' is due to the formation of nitrite by the action of bacteria upon the saltpetre. The nitrite formed reacts with the blood colouring matter present to form a special pigment, nitroso-hæmoglobin. It is shown that a satisfactory English bacon can be made by using only sodium chloride and sodium nitrite in the pickle, and that bacteria and nitrate are not essential for the development of the flavour. A very small content of free nitrite, as low as ten parts per million in the final product, is sufficient to produce a satisfactory flavour and colour. The report indicates the possibility of recasting the present practice so as to give the curer better control over the quality of this product.

\section{The Stoic}

THE April number of the Stoic represents, not the "famed Athenian Porch", but Stowe School, which, starting at one of the great houses which flourished in the eighteenth century, has long since won its way to recognition on a par with older foundations. The school magazine is one of the best we have seen, including literary matter as well as the usual records of activities. Stowe is now responsible for two London clubs for boys. It produces its own films, which have dealt with several classes of animals and plant-life, while the Natural History Society, started last year, keeps a journal of work done which is well spoken of. The school evidently enjoys many things besides the normal curriculum. The illustrations make a good show and include a lively "Decorated Black-out Screen" designed by a young artist.

\section{Earthquakes in the United States and in Italy}

ON Saturday and Sunday, May 18 and 19, severe earthquake shocks were experienced in the southwestern United States and in Italy. In the United States eleven shocks were felt at places so far apart as 800 miles in Southern California and Arizona. The town of Imperial is reported in ruins, with five people killed and many injured. Owing to the disruption of communications, further details are not yet available. The place most affected in Italy appears to have been San Servo.

\section{Other Recent Earthquakes}

REPORTS from the seismological observatories at Kew (England) and De Bilt (Holland) confirm that there were two large earthquakes on May 4 and one on May 5. At Kew the first commenced recording at $7 \mathrm{~h} .35 \mathrm{~m}$. 55s. G.M.T. on May 4, and the epicentre was estimated to be distant $8,500 \mathrm{~km}$. The second was received at Kew at $21 \mathrm{~h}$. $10 \mathrm{~m}$. 7s. G.M.T. on the same day, with an estimated epicentral distance of $4,770 \mathrm{~km}$., and gave rise to ground amplitudes of $54 \mu$. The third commenced recording at $2 \mathrm{~h} .16 \mathrm{~m}$. 40s. G.M.T. on May 5 at Kew, and the estimated epicentral distance was $9,750 \mathrm{~km}$. These readings have been confirmed by equivalent readings from De Bilt. Dr. G. van Dyk is of the opinion that the first on May 4 originated near the Aleutian Islands, which has recently been observed to be seismically active (NATURE, May 4, p. 701 and earlier issues) and that the second on May 4 may have come from an easterly azimuth.

\section{The Night Sky in June}

THE nights around the summer solstice on June 21 are shorter than $7 \frac{1}{2}$ hours in the latitude of London, reckoned from sunset to sunrise; excluding twilight (nautical) darkness lasts only about three hours. The moon is new on June 6 and full on June 19. Venus, which is still a brilliant evening star at the beginning of the month, draws rapidly towards the sun's place and is at inferior conjunction on June 26. Mercury is also an evening star in conjunction with Venus on June 12 and with Mars on June 17 ; on June 24 Mercury is at greatest elongation (25 east). Mars is getting less easy to see; it is close to Venus on June 7. Jupiter and Saturn are both morning stars, the former rising soon after $1 \mathrm{~h}$. $30 \mathrm{~m}$. U.T. on June 16 , followed $\frac{1}{4} \mathrm{hr}$. later by Saturn. At dusk in midJune, the red star Antares is about south. Areturus has already southed, while Vega is some, 3 hours before the meridian. The constellations, Bootes, Hercules and Ophiuchus contain some interesting double stars of which $\varepsilon$ Boötis $\left(2 \cdot 8^{\prime \prime}\right)$, $\xi$ Bootis $\left(5 \cdot 1^{\prime \prime}\right)$, $\alpha$ Herculis $\left(4 \cdot 8^{\prime \prime}\right)$ and 70 Ophiuchi $\left(6 \cdot 6^{\prime \prime}\right)$ are good examples. Between $\eta$ and $\zeta$ Herculis may be glimpsed with the naked eye under favourable conditions the great star cluster, $M 13$, the distance of which is of the order 35,000 light years. The outer part of the cluster can be resolved into stars with a $2 \frac{1}{2}$ - or 3 -inch refractor. The Scorpiid meteors are at their greatest frequency about June 4, their radiant point being north, following Antares.

\section{Announcements}

The Editors of NATURE have decided that, for the time being, the receipt of the manuscript of contributions cannot be acknowledged. Furthermore, it is found essential to reduce the number of proofs sent to the author of contributions submitted to one. This proof must be accepted as an acknowledgement of receipt of the copy.

Among his personal assistants, the Prime Minister has appointed Prof. F. A. Lindemann, F.R.S., professor of experimental philosophy in the University of Oxford, for advice concerning statistics and research.

Dr. H. SHAw, keeper in the Department of Physics and Geophysics at the Science Museum, has been appointed acting director of the Museum during the absence of Brigadier E. E. B. Mackintosh. 